\title{
Kaapvaart in de tweede en derde Engelse oorlog ${ }^{*}$
}

\author{
J. R. BRUIJN
}

De Engelse zeeoorlogen hebben over het algemeen vrij veel belangstelling van historici genoten. Zowel van Engelse als van Nederlandse zijde werden de campagnes ter zee bestudeerd evenals enkele zeeslagen en expedities in het bijzonder. De achtergronden van deze oorlogen zijn met name door Elias en Wilson geanalyseerd ${ }^{1}$. Economisch gezien stonden in de eerste oorlog (1652-1654) hoofdzakelijk Europese zaken centraal, in de tweede (1665-1667) meer buiten-Europese. Engeland's verbond met het Frankrijk van Lodewijk XIV gaf de derde oorlog (1672-1674) een meer politieke achtergrond.

\section{WINST VOOR DE ENGELSE KOOPVAARDIJVLOOT}

Enige jaren geleden belichtte de Engelse economisch historicus Davis een nieuw aspect van deze oorlogen, toen hij stelde dat de Engelse koopvaardijvloot ten zeerste van de oorlogshandelingen profijt had getrokken. Grote aantallen Nederlandse koopvaarders werden door Engelse oorlogsschepen en kapers buitgemaakt en door reders opgekocht en gebruikt voor hun scheepvaart. Onder deze buit waren vooral veel fluiten en deze bij uitstek op het goedkoop vervoer van massagoederen gebouwde schepen verschaften Engeland een scheepstype, dat het nog miste bij zijn groeiende handel en scheepvaart. Doordat deze prijsschepen over het algemeen groter van inhoud waren dan de Engelse, kon, zo zegt Davis, tot 1675 het aandeel van in het buitenland gebouwde tonnage in de Engelse koopvaardijvloot tot zelfs vijftig procent stijgen. Scheepswerven in Engeland waren tot dan toe niet in staat geweest op grote schaal schepen van een type zoals de fluit te bouwen, maar zij

* Dit onderwerp vormde in een andere en engelstalige versie een 'paper' voor het tiende International Congress for Maritime History over 'Privateering and Piracy', gehouden op 22 en 23 augustus 1975 te San Francisco. Het onderzoek werd in het NIAS te Wassenaar verricht.

Voor hulp en raad wil ik gaarne dr. R. W. Unger (Grijpskerke/Vancouver), mej. L. Zuiderbaan en G. J. A. Raven (beiden te Leiden) dankzeggen en zeer in het bijzonder C. A. Davids (Leiden), zonder wiens inspanningen dit artikel wellicht ongeschreven was gebleven.

1. J. E. Elias, De tweede Engelsche oorlog als het keerpunt in onze betrekkingen met Engeland (Amsterdam, 1930) en Ch. Wilson, Proflt and Power. A Study of England and the Dutch Wars (Londen, 1957). 
kregen door deze oorlogsbuit tijd en gelegenheid zich op een nieuwe vraag voor te bereiden. De Republiek verloor in de eerste oorlog 1.000 a 1.700, in de tweede 522 en in de derde oorlog 500 schepen $^{2}$.

Davis heeft op deze wijze een interessant facet van de Engels-Nederlandse conflicten onder de aandacht gebracht en daardoor ook de betekenis en de omvang van de kaapvaart in het licht gesteld. Immers, de meeste vijandelijke koopvaarders en vissersschepen werden veroverd door kapers. Over de Engelse en Nederlandse kaapvaart in deze jaren is echter niet veel bekend. Het aandeel van Engelse kapers in de oorlogsbuit is verborgen. Alleen voor de tweede Engelse oorlog kan Davis een nauwkeurig totaal cijfer geven, voor de andere twee zijn het schattingen. Samuel Pepys meende in 1692, dat in het geheel 2.000 tot 2.500 Nederlandse schepen waren prijsgemaakt. Hiertegenover kan van Nederlandse kant zelfs niet bij benadering enig cijfer over de omvang van de Nederlandse buit gesteld worden. Aan de hand van Engelse bronnen doet Davis dit wel: in totaal verloren de Engelsen gedurende deze drie oorlogen niet meer dan vijfhonderd schepen aan de Republiek. Engelse tijdgenoten meenden dat hun land viermaal meer prijzen maakte dan het zelf schepen kwijt raakte ${ }^{3}$. Het hoeft geen verbazing te wekken, dat in de veel grotere Nederlandse koopvaardij- en vissersvloot meer slachtoffers vielen, maar het lijkt toch vreemd, dat kapers en oorlogsschepen van de Republiek in deze drie confrontaties zo weinig oorlogsbuit behaald zouden hebben.

\section{EEN TEKORT AAN INFORMATIE OVER DE NEDERLANDSE KAAPVAART}

Kaapvaart vond weinig aandacht in de Nederlandse literatuur. Juridische aspecten werden door Van Hamel en Oudendijk belicht, De Meij analyseerde onlangs de watergeuzen, terwijl Vrijman kaapvaart en zeeroof in de Nederlanden tot in de eerste helft van de zeventiende eeuw schetste ${ }^{4}$. Voor de drie Engelse oorlogen treft men in feite alleen in het negentiende-eeuwse en nog zo waardevolle handboek voor de geschiedenis van de marine van J. C. de Jonge op verspreide plaatsen passages over kaperactiviteiten aan. En hoewel deze auteur meende niet in details over de

2. R. Davis, The Rise of the English Shipping Industry in the Seventeenth and Eighteenth Centuries (Londen, 1962; 2e dr., Newton Abbot, 1972) 48-54.

3. Davis, The Rise, 51 noot 6, 315-316; J. R. Tanner, ed., 'Samuel Pepys's Naval Minutes', Navy Records Society, LX (1926) 270.

4. J. A. van Hamel, 'De betekenis van kaapvaart- en blokkaderecht in de Republiek der Verenigde Nederlanden', Varia Iuris Gentium. Liber amicorum aangeboden aan J. P. A. François (Leiden, 1959) 140-159; J. K. Oudendijk, 'De kaperbrieven van Willem van Oranje', Bijdragen voor de geschiedenis der Nederlanden, XIX (1964) 133-150; J. C. A. de Meij, De watergeuzen en de Nederlanden 1568-1572 (Amsterdam-Londen, 1972); L. C. Vrijman, Kaapvaart en zeeroverij (Amsterdam, s.a.). 


\section{J. R. BRUIJN}

kaapvaart te hoeven treden 'als zijnde zulks van minder aanbelang', geeft hij toch wel zoveel incidentele informatie, dat de hierboven genoemde cijfers over Engelse verliezen reeds als onwaarschijnlijk laag voorkomen. Dat de Nederlanders alleen in de derde oorlog 2.703 schepen veroverd zouden hebben, is evenwel weer een ander uiterste ${ }^{5}$. Het zijn de Engelsen Clark en Bromley, die met name de activiteiten van Zeeuwse kapers in de Negenjarige oorlog (1689-1697) en de Spaanse Successie oorlog (1702-1713) bestudeerden en aantoonden van welk een omvang deze wel waren ${ }^{6}$.

Is er een verklaring voor dit gebrek aan kennis over Nederlandse kaapvaart en voor de geringe dunk van Pepys en Davis over Nederlandse oorlogsbuit op de Engelsen behaald? Deze is moeilijk nauwkeurig te geven, wel kunnen er enkele veronderstellingen gemaakt worden. Zijn de Nederlanders in deze niet het slachtoffer van hun reputatie, dat zij in de zeventiende eeuw de vrachtvaarders van Europa waren en daardoor altijd een gemakkelijke prooi in tijd van oorlog? Hiertoe droeg wellicht sterk bij, dat Duinkerker en andere Vlaamse kapers in de tweede helft van de Tachtigjarige oorlog vele Nederlandse schepen prijsmaakten. De Belg Baetens, die onlangs in een uitvoerig artikel de resultaten van een onderzoek naar de Zuidnederlandse kaapvaart analyseerde, vermeldt dat tussen 1627 en 1634 niet minder dan 1.499 Noordnederlandse schepen verloren gingen en 495 tussen 1642 en 1646 . Verder had de Nederlandse oorlogsvloot geregeld alle beschikbare zeelieden en soldaten nodig in de grote zeeslagen tegen de Engelse en Franse vloten. Ruim twintigduizend man waren aan boord van de vloten van Van Wassenaer Obdam en De Ruyter. Problemen bij het werven van voldoende personeel waren normaal. Soms waren de problemen zelfs nijpend. De Staten-Generaal verboden vaak het uitzeilen van koopvaarders en kapers. Voor menig zeehistoricus zijn bovendien de Engelse oorlogen sinds A. T. Mahan's The Infiuence of Sea Power upon History (1890) conflicten, gekenmerkt door acties van grote vloten, die elkaars nederlaag in een zeeslag zochten en konvooien van koopvaarders beschermden. Voor kaapvaart was geen aandacht.

5. J. C. de Jonge, Geschiedenis van het Nederlandsche zeewezen (5 dln, 2e dr.; Haarlem, 18581862) zie onder andere deel II (1859) 2-5, 53, 265, 332-337, 355,474-478. Van Hamel, 'Kaapvaarten blokkaderecht', 148 vermeldt voor Zeeland tussen december 1665 en augustus 1667 honderdveertig prijsverklaringen en voor Engeland in de periode 1664 tot 1667 duizend gevallen! 6. G. N. Clark, 'English and Dutch Privateers under William III', Mariner's Mirror, VII (1921) 162-167, 209-217; idem, The Dutch Alliance and the War against French Trade, 1668-1697 (Manchester, 1923); J. S. Bromley, 'Les corsaires zélandois et la navigation scandinave pendant la guerre de succession d'Espagne', in : M. Mollat, ed., Le navire et l'economie maritime du Nord de l'Europe (Parijs, 1960) 93-109; idem, 'Some Zeeland Privateering Instructions: Jacob Sautijn to Captain Salomon Reynders, 1707', in: R. Hatton en J. S. Bromley, ed., William III and Louis XIV. Essays 1680-1720 by and for M. A. Thomson (Liverpool, 1968) 162-189.

7. R. Baetens, 'Organisatie en resultaten van de Vlaamse kaapvaart in de $17 \mathrm{e}$ eeuw', Mededelingen van de Marine Academie, XXI (1969-1970) 89-125. 
Er zijn ook nog redenen van praktische aard, die het onderzoek naar kaperactiviteiten bemoeilijken. De vijf admiraliteitscolleges waren de organen die kaperbrieven uitreikten en als prijsgerechtshoven optraden. Een centrale administratie, zoals in Engeland met het 'Court of Admiralty' ontbreekt en de admiraliteiten hielden bovendien meestal geen afzonderlijke boeken bij voor hun kaperijzaken. Vijf gescheiden archieven, weliswaar nu verenigd in de admiraliteitsarchieven in het Algemeen Rijksarchief te Den Haag, moeten geraadpleegd worden. Deze archieven zijn niet meer compleet, want in 1771 verbrandde het gebouw van de Friese admiraliteit te Harlingen en in 1844 werd in Den Haag het departement van marine, waar de vijf archieven toen lagen opgeslagen, in de as gelegd. Slechts een deel kon gered worden ${ }^{8}$. Gelukkig had De Jonge toen juist de eerste editie van zijn Geschiedenis van het Nederlandsche zeewezen voltooid. Deze verliezen betekenen wel, dat onder meer voor de kaapvaart een enigszins volledig onderzoek nooit meer mogelijk is.

\section{ZIJN GROOTSCHEEPSE NEDERLANDSE KAPERACTIVITEITEN WAARSCHIJNLIJK?}

Tegenover het voorafgaande zou men kunnen poneren dat juist de Nederlanders bij uitstek geschikt waren voor het bedrijf van de kaapvaart en dat een Engelse superioriteit in deze geen vanzelfsprekend gegeven behoeft te zijn. Immers de meeste handelsvaarten, de walvisvangst en de zeevisserij werden doorgaans tijdens de Engelse oorlogen in het voorjaar en in de zomer stilgelegd. Alleen de vaart van de VOC, en de WIC en de kustvisserij werden daarvan uitgezonderd. Niet alle reders zullen werkeloos zijn gebleven of zullen hun activiteiten onder neutrale vlag hebben voortgezet. Het uitrusten van een kaperschip bood vervangend emplooi. De Staten-Generaal vestigden hierop zelfs nadrukkelijk de aandacht ${ }^{9}$. Zeker in de herfst- en wintermaanden, wanneer de oorlogsvloot opgelegd was en vaart op de Oostzee, naar Archangel of ter walvis niet doenlijk was, bestond aan zeelieden geen gebrek. In de opeenvolging van oorlogen, waarin de Republiek in de zeventiende eeuw verwikkeld was, gingen sommige reders zich speciaal op dit bedrijf toeleggen. De decentralisatie van de marine en van de heffing en het beheer van in- en uitvoerrechten over vijf uiteengelegen en soms naijverige administraties kon ook verschillen in het toezicht op de kaapvaart tot gevolg hebben.

Nederlandse schippers wisten de weg in Europese en buiten-Europese wateren. Het is dan ook niet waarschijnlijk dat zij alleen in de nabijheid van de eigen kust hun buit afwachtten, maar het is veeleer aannemelijk dat zij opereerden in gebieden

8. Zie J. de Hullu, De archieven der admiraliteitscolleges (Den Haag, 1924) 60-64. Gaarne dank ik de heren drs. G. W. van der Meiden en drs. B. J. Slot, verbonden aan het Algemeen Rijksarchief, voor hun medewerking bij het raadplegen van een aantal van deze admiraliteitsbescheiden.

9. Zie bijvoorbeeld Algemeen Rijksarchief (ARA), Admiraliteitsarchieven (AA) 2484, 7.2.1665. 
waar de voornaamste vijandelijke handelsroutes lagen. Hierbij werden zij begunstigd door de omstandigheid, dat Frankrijk bijvoorbeeld in de tweede Engelse oorlog een bondgenoot van de Republiek was, terwijl Spanje toen neutraal en in de derde oorlog zelfs een bondgenoot was. De Engelse scheepvaart in het Kanaal en de handel met Zuid-Europa, Afrika en de West waren uiterst kwetsbaar voor kapers,die vanuit Franse of Spaanse havens konden opereren. Kaapvaart werd nog aantrekkelijker, toen in de derde oorlog ook Franse schepen buitgemaakt konden worden. Kaapvaart of commissievaart was in de Republiek geen nieuw bedrijf. Na de tijd van de watergeuzen was er een onafgebroken strijd tegen de Vlaamse vloot en kapers gevoerd. Oorlogsschepen trachtten de Vlaamse havens te blokkeren en kapers opereerden tegen Spaanse, Vlaamse en neutrale scheepvaart op die havens. Vooral het nabijgelegen Zeeland was bij deze verwikkelingen nauw betrokken. Bovendien had de WIC kaapvaart buiten Europa gestimuleerd.

In het licht van deze veronderstellingen en tegen de achtergrond van de genoemde Engelse en Nederlandse gegevens heb ik gepoogd nauwkeuriger vast te stellen van welke omvang en betekenis de kaapvaart in de Republiek tijdens de Engelse oorlogen is geweest. Vele documenten van de admiraliteiten zijn verloren gegaan of kunnen niet meer geraadpleegd worden zonder onherstelbare schade aan de stukken toe te brengen. Toch konden van twee admiraliteitscolleges, die waarschijnlijk de grootste aantallen kapers onder hun jurisdictie hadden - de colleges van Zeeland en Amsterdam - redelijk volledige gegevens betreffende de tweede en derde Engelse oorlog gevonden worden, van dat te Rotterdam vrijwel alleen voor de derde oorlog. Het onderzoek bleef daarom beperkt tot deze twee oorlogen. Van de colleges in het Noorderkwartier en in Friesland ontbreekt elk benodigd materiaal. Van een inzicht in het geheel van de kaapvaart kan dus geen sprake zijn en cijfers over aantallen kapers en prijzen zijn dus nooit volledig.

\section{DE ORGANISATIE VAN DE KAAPVAART}

Ter kaapvaart gaan was een wettige activiteit wanneer men van de hoogste autoriteit in het land in tijd van oorlog een officiële volmacht of commissie daartoe bezat. In zo'n commissiebrief stond deze autoriteit de commissiehouder toe vijandelijke schepen en goederen te veroveren of te vernietigen. Door de 'onrechtveerdige ende violente proceduren' van de vijand was wraak gerechtvaardigd en vergoeding voor geleden verliezen noodzakelijk. De data van uitgifte en de namen van de houders van kaperbrieven, vaak ook 'commissies van retorsie' genoemd, werden geregistreerd. De Staten-Generaal reikten deze commissies uit, totdat dit in 1672 door Willem III als kapitein-admiraal werd overgenomen. De geldigheid verliep automatisch als er vrede gesloten werd. Ook tussentijds konden de Staten-Generaal of de 
Prins een commissie intrekken, als de commissiehouder bepaalde verplichtingen niet nakwam. Elke commissiebrief was door één van deze Haagse instanties ondertekend, maar de eigenlijke uitreiking geschiedde door één van de admiraliteitscolleges.

Een commissiebrief werd aangevraagd door particulieren. Meestal waren het kooplieden, die optraden als boekhouder van een schip dat voor de kaapvaart was uitgerust. De eigendom van het schip was, zoals normaal in de scheepvaart, verdeeld over een aantal partenhouders onder wie de boekhouder. Soms verenigden zich enkele boekhouders tot een 'directie', zoals in 1665 te Vlissingen. Ook kon één persoon optreden als boekhouder van verschillende kaperschepen tegelijk. Niet alleen het volledige financiële beheer berustte bij de boekhouder, maar ook de voorbereiding van de reis, de uitrusting en bevoorrading van het schip. Ook droeg hij, in samenwerking met functionarissen van de admiraliteit de zorg voor de afwikkeling van de buit. Ook de keuze van een kapitein was zijn taak en aan deze gaf hij speciale instructies voor de reis mee. Samen met de kapitein werden officieren en manschappen geworven. Als garantie voor een goed gedrag eiste de admiraliteit borgen voor een bedrag van niet minder dan twintigduizend gulden; de boekhouder diende de namen van de borgen op te geven. Enkele gevallen zijn bekend, waarin borgen werden aangesproken of officieel van hun verplichtingen werden ontslagen na inlevering van een commissiebrief.

Elke kapitein moest een journaal van zijn reis bijhouden en het na afloop bij het admiraliteitscollege voor controle inleveren. Voor de president van het college bezwoer hij prijzen en hun bemanningen behoorlijk te behandelen; daarbij werd uitgegaan van zijn 'bequamheyt ende vromicheyt'. Plundering was verboden en van elke prijs moesten de schipper en één van de officieren aan wal gebracht worden om bij de prijsverklaring gehoord te worden. Wenste een boekhouder een andere kapitein op het schip, dan diende hij hiervoor bij de admiraliteit toestemming te vragen. Kaapvaart was een speculatieve handelsonderneming, waarbij het behalen van winst het oogmerk was, maar het kaperschip werd geacht onder toezicht en met instemming van de overheid te opereren en hierbij kon het zonodig op 'alle hulp ende assistentie' van oorlogschepen aanspraak maken ${ }^{10}$.

De admiraliteiten traden namens de Staten-Generaal of de prins van Oranje als prijzengerechtshoven op. Over de gang van zaken in deze jaren zijn niet veel gegevens aangetroffen. Een kapitein moest zijn buit zoveel mogelijk opbrengen in havens in het ressort van zijn admiraliteit. Hieraan werd niet strak de hand gehouden,

10. Teksten van commissiebrieven bevinden zich bijvoorbeeld passim in de commissie- en instructieboeken van de admiraliteiten van Amsterdam en Zeeland (ARA, AA 1328 en 2429-2430). Zie ook C. Cau, ed., Groot Placaet-boeck, II (Den Haag, 1664) 1531-1536: Bromley.'Some Zeeland Privateering Instructions', 166-174 en Baetens, 'Organisatie', 91-97. Voor kwesties met borgen: ARA, AA 2485, 21.4.1665; 2491, 21.4.1667; 2492, 29.8.1667; 2499, 24 en 28.3.1674; zie ook $2484,20.1 .1665$. 


\section{J. R. BRUIJN}

want menige Zeeuwse prijs werd bijvoorbeeld in Amsterdam opgebracht en vele andere in buitenlandse havens. In dit laatste geval speelden een te grote afstand tussen plaats van verovering en thuishaven, veiligheid en aard van de lading meestal een beslissende rol. Leden van het admiraliteitsbestuur verklaarden een schip voor 'goede prijs', waarna een openbare verkoping bij opbod volgde. Deze verkopingen, die onder leiding van de vendumeester van de admiraliteit stonden, werden van te voren door aanplakbiljetten aangekondigd. In Amsterdam was één vendumeester, in Zeeland verschillende, zoals in Vlissingen, Middelburg en Veere.

Volgens Baetens bracht de buit bij openbare verkoop meestal niet meer dan de helft van de eigenlijke waarde op ${ }^{11}$. De grote spreiding van veilingplaatsen over de Republiek en over buitenlandse havens voorkwam wellicht overvoering van plaatselijke markten, zoals in Duinkerken het geval was. De boekhouder ontving nooit de gehele opbrengst, want er werden verschillende bedragen afgetrokken. Van het in oude plakkaten genoemde vijfde part ten behoeve van het land, werd geen spoor gevonden. Onkosten gemaakt bij de opslag en bewaring van goederen en schepen en veilingkosten werden als 'ongelden' afgetrokken. Het was een steeds wisselend bedrag. Een vast gegeven was de inhouding van één procent van de opbrengst (de 'centesimo') als presentiegeld voor de leden van het admiraliteitsbestuur bij de prijsverklaring en de verkoop. Bij de Zeeuwse admiraliteit bestond dit gebruik aanvankelijk niet, maar toen de raad van een Zeeuwse representant in het Amsterdamse college over dit presentiegeld hoorde, werd het in september 1665 onmiddellijk ingevoerd, en wel met terugwerkende kracht tot het begin van de oorlog ${ }^{12}$.

Naast de 'centesimo' werden ook de zogenaamde rantsoengelden ingehouden. Deze beliepen vijf procent en hadden een uiteenlopende bestemming. Hiervan was zeven twaalfde deel voor de armenbus, een achtste deel voor het gasthuis en de rest (zeven vierentwintigste) voor de secretaris, de vendumeester en de controleur van de admiraliteit. In de armenbus te Amsterdam kwam zo bijvoorbeeld over de jaren 1665 tot 1667 ruim $f$ 48.000.- terecht. Sinds 1672 moesten de boekhouders ook nog tien procent afstaan aan de prins van Oranje, de 'tiende penning'. Hoe de boekhouder het bedrag dat hij uiteindelijk van de admiraliteit via de vendumeester ontving, verdeelde, onttrekt zich aan onze waarneming. De kapitein en zijn bemanning kregen een vooraf vastgesteld deel van de opbrengst, dat zij naar rang verdeelden. Dit buitgeld kwam bovendien boven hun normale gages. Voor het bevrijden van Nederlandse schepen uit vijandelijke handen werd een zesde deel van de waarde aan de boekhouder uitgekeerd $^{13}$.

\section{Baetens, 'Organisatie', 105.}

12. ARA, AA, 2486, 14.9.1665; zie ook bijvoorbeeld 2489, 21.7.1666.

13. Voorbeelden van de verdeling van de rantsoengelden bijvoorbeeld in: ARA, AA 1891-1894; voor de tiende penning onder andere C. Cau, ed., Groot Placaet-boeck, III (Den Haag, 1683) 232233. Verder Rijksarchief in Zeeland, Staten van Zeeland 3075, 27.9.1674. 
KAPERKAPITEINS: HUN AANTALLEN, BOEKHOUDERS EN SCHEPEN (1665-1674)

Aan de hand van commissie- en instructieboeken, notulen en enkele andere bescheiden kan vastgesteld worden hoeveel en welke kaperkapiteins tijdens de tweede en derde Engelse oorlog onder de jurisdictie van de admiraliteiten van Amsterdam en Zeeland en op welk moment hun bedrijf uitoefenden. In totaal waren het er op zijn minst voor Amsterdam zevenendertig in de tweede en vijfenzeventig in de derde oorlog en voor Zeeland drieënnegentig in de tweede en hondervierentachtig in de derde oorlog. Namen van respectievelijk vijf en vijftien kapers van de admiraliteit van de Maze, die bij verkopingen van buit betrokken waren, werden toevallig aangetroffen ${ }^{14}$.

Onder de kapiteins, ook wel 'kapiteins-avonturier' genoemd, die in de derde oorlog ter kaapvaart voeren, waren er niet veel die in de tweede al ervaring opgedaan hadden: in Amsterdam vijf en in Zeeland vijfentwintig. Wat wel opvalt, is de vrijwel exacte verdubbeling van de aantallen. Kaapvaart heeft ook in vergelijking met volgende oorlogen in de driejaren van 1672 tot en met 1674 een hoge vlucht genomen, want in de negen jaren van 1689 tot en met 1697 en gedurende de twaalf jaren van de Spaanse Successie oorlog konden voor Amsterdam respectievelijk minimaal vijfennegentig en honderdzes kapers geteld worden, terwijl Bromley voor Zeeland het aantal kapers in de periode van 1702 tot 1713 op ruim driehonderd schat ${ }^{15}$.

Dezelfde bronnen als voor de kapiteins vermelden ook vaak de namen van de boekhouders, helaas geldt dat niet voor Amsterdam. Van Zeeuwse kapers in de tweede oorlog is ongeveer de helft van de boekhouders bekend, van de boekhouders in de derde oorlog kennen wij vrijwel alle namen. Hieruit blijkt dat tenminste twaalf boekhouders hun activiteiten continueerden en meestal op grotere schaal. De namen van Gelein en Daniël Blonkenbijle, Jacob van Hoorn, Abraham van Pere vaak samen met Pieter van Rhee, Benjamin Raule en Laurens Willemsz. Verpoorte verdienen genoemd te worden. Van Hoorn en Van Pere bijvoorbeeld waren kooplieden en regenten te Vlissingen; Van Pere bezat onder meer grote belangen in de West. Vlissingen en Middelburg waren zonder twijfel de centra van de Zeeuwse kaapvaart. Ook de herkomst van menig kaperkapitein wijst hierop.

Het merendeel van de boekhouders had maar één of twee schepen in zee. Over hun verdere zakelijke belangen kan zonder nader gedetailleerd onderzoek niets gezegd worden. Enkele oud-kaperkapiteins fungeerden als boekhouders, zoals bijvoorbeeld Michiel Brijs, Anthonie Crijnsen de Vlaminck, Jacques Cool en Anthonie Claesz.

14. ARA, AA 636-637, 1328, 2429-2430 en 2484-2499, passim.

15. Idem, 1328-1329 en Bromley, 'Some Zeeland Privateering Instructions', 165 noot 11. Clark ('English and Dutch Privateers', 209) neemt vanzelfsprekend aan dat Amsterdamse kapers van geen betekenis zijn. Hoe onjuist! 


\section{J. R. BRUIJN}

Stokvis ${ }^{16}$. Hun ervaring zal van nut geweest zijn. Menigmaal bestond er duidelijk een familierelatie tussen boekhouder en kapitein. De grootste kaperactiviteiten in de derde oorlog werden onmiskenbaar door Benjamin Raule (1634-1707) ontplooid. Raule was koopman in Middelburg en bekleedde diverse functies in het stadsbestuur. Hij behoorde tot de vooraanstaanden in de Zeeuwse hoofdstad, mede door een aanzienlijk huwelijk en hij trad onder meer op als thesaurier (1668) en als chepen $(1669,1670,1674)$. Zijn handelscontacten strekten zich uit naar Hamburg, Spanje, Portugal en vooral naar Frankrijk en haar Westindische eilanden Guadeloupe en Martinique. Als boekhouder zond hij diverse schepen daarheen uit. In walvisvaarders bezat hij ook parten. Raule is vooral bekend geworden door zijn latere carrière in Brandenburg, waar hij allerlei maritieme activiteiten van commerciële en militaire aard ontplooide. In 1675 verliet hij de Republiek. Hij was toen met schulden beladen, die waarschijnlijk reeds voortkwamen uit handelstransacties vóór 1672 en die door de oorlog met Frankrijk verergerd waren. Tot nu toe is in de literatuur over Raule geheel voorbijgegaan aan 's mans belangen bij de kaapvaart. Slechts wordt gememoreerd, dat hij in 1675 de Grote Keurvorst tien kaperschepen in diens strijd tegen Zweden aanbood ${ }^{17}$.

Uit de onvolledige opgaven van Zeeuwse boekhouders in de tweede Engelse oorlog blijkt dat Raule bij tenminste vier kaperschepen als boekhouder fungeerde, tweemaal samen met François van der Beke. In de derde oorlog voeren in ieder geval achttien kapers onder zijn leiding. Hij was meestal de grootste partenhouder en zo is bijvoorbeeld van de drie schepen, de 'Revenge' met kapitein Cornelis Rees, de 'Zilveren Fontein' met Andries Bergenaar en de 'Blauwe Reiger' met Cornelis van Leenen, bekend dat hij in 1673 de helft van de parten bezat, terwijl de andere helft bij de Amsterdamse kooplieden Jacob van Foreest, Pieter van Rijn en Bartholomeus Reael berustte. Het is niet duidelijk in hoeveel schepen precies Raule belangen had, want het aantal kapiteins is daarvoor geen vaste aanwijzing omdat zij nog wel eens van rederij wisselden. Een paar schepen voeren met buitenlandse papieren. Hij gebruikte enkele van zijn koopvaarders 'ter kape'. Raule bleef in zijn kaperbedrijf niet achter bij de Sautijns, die in de Negenjarige oorlog vijftien uitredingen de-

16. Voor Brijs: ARA, AA 2429, 14.8.1672 en 2430, 15.1.1674; voor De Vlaminck 2429, 24.12. 1666 en 2430, februari 1676; voor Cool 2429, 26.7 .1672 en 2430, 8.12.1673; voor Stokvis 2429, 28.9.1672 en 2430, 10.10.1673.

17. Over Raule hebben onder anderen de volgende auteurs geschreven: R. Schück, Brandenburg-Preussens Kolonial-Politik (Leipzig, 1889); R. Hapke, 'Benjamin Raule und seine Handlungsbücher', Economisch-Historisch Jaarboek, IX (1923) 214-220; G. Gieraths, 'Benjamin Raule, sein Leben und insbesondere seine volkswirtschaftlichen Ansichten', ibidem, X (1924) 219-302; J. A. van Hamel, 'Een Nederlander als de geniale organisator van Pruisische zee- en koloniale macht. Benjamin Raulé (1634-1707)', Historia, II (1936) 217-222 en F. Jorberg, 'Benjamin Raule', Mededelingen Nederlandse vereniging voor zeegeschiedenis, X (1965) 1-9. Zie ook I. Schöffer, Het nationaal-socialistische beeld van de geschiedenis der Nederlanden (Arnhem-Amsterdam, 1956) 108, 203. 
den, evenmin als de Blonkenbijles met elf en Verpoorte met tien tijdens de jaren 1672 tot $1674^{18}$.

Het fregat was veruit het meest gebruikte scheesptype in de kaapvaart. Deze indruk krijgt men althans uit de veelvuldige vermeldingen, maar wat onder deze benaming precies verstaan werd, blijkt niet. Zelfs heel kleine schepen werden ermee aangeduid. Deze vermeldingen zijn zuiver incidenteel, overzichten of lijsten bestaan niet. Dat geldt ook voor de bewapening en de bemanning. Vele schepen hadden slechts enkele kanonnen aan boord, andere konden met oorlogsschepen vergeleken worden. De 'Nassau' onder Cornelis Janszoon met zesendertig stukken geschut was wel de zwaarste (1665). Over het algemeen liep de bewapening uiteen van vier tot tweeëntwintig stukken en waarschijnlijk waren kaperschepen die dichtbij hun thuishaven in de Noordzee voeren lichter bewapend dan die verder weg opereerden, wat ook opgaat voor de bemanning. Van deze laatste schepen zijn soms aantallen opvarenden van vijftig tot honderd bekend, van de eerste variëren de aantallen tussen de twintig en veertig man. Een gemiddelde kan niet gegeven worden. Uit de jaren 1691-1692 noemt Clark een lijst van eenendertig Zeeuwse kapers met 948 zeelieden, waarbij hij tevens meent dat de Engelse kapers bemanningen hadden van tien tot veertig koppen ${ }^{19}$.

Sommige namen van de schepen zijn kleurrijk, zelfs vreemd. Wat te denken van de 'Moeder en Maagd', die op kaapvaart gaat, tot tweemaal toe? Veruit de meeste scheepsnamen zijn de in de koopvaardij gebruikelijke ${ }^{20}$, maar een aantal lijkt toch wel voor de gelegenheid gegeven te zijn, zoals de 'Wraak', het 'Rad van Avontuur', de 'Oranje in het Hart', het 'Geweld van Rotterdam' en de 'Verstoorde Leeuw', maar de 'Getergde Kaasboer' spant daarbij de kroon. Niet minder dan drie schepen voeren die naam.

\section{BEPERKINGEN AAN KAPERS OPGELEGD}

Direct na het uitbreken van de oorlog, in januari 1665, wekten de Staten-Generaal tot kaapvaart op. Tot de eersten die hieraan gevolg gaven, behoorde een groep Vlissingse boekhouders onder leiding van Abraham van Pere, die zich in de zogenoemde 'Directie van de Nieuwe Equipage' verenigden. Gemeenschappelijk vroe-

18. Gemeentearchief Amsterdam, Notariële Archieven 3756/321 ${ }^{\mathrm{v}}$, acte van 30.5.1673; Rijksarchief in Zeeland, Handschriften 198. Verder Bromley, 'Some Zeeland Privateering Instructions', 166.

19. Zie bijvoorbeeld ARA, AA 2485, 16.5.1665; 2486, 14.9.1665; 2498, 19.5, 5.6, 1.7 en 10.7. 1673; Clark, 'English and Dutch Privateers', 210-211, 216 en Bromley, 'Some Zeeland Privateering Instructions', 165 noot 11.

20. Zie W. Voorbeijtel Cannenburg en J. P. Kruseman, Scheepsnamen vroeger en nu (Amsterdam, 1960). 


\section{J. R. BRUIJN}

gen zij reeds op 4 februari niet minder dan vierentwintig commissiebrieven aan bij de Zeeuwse admiraliteit. Den Haag werd om snelle toezending verzocht. Zestien commissiebrieven konden spoedig uitgereikt worden, maar ook de overige schepen kozen zee. Op de Zeeuwse vraag een hoeveelheid blanco commissiebrieven te sturen, opdat tijdverlies met het heen- en weerzenden van bescheiden vermeden kon worden, gingen de Staten-Generaal niet in. Grotere Zeeuwse autonomie in deze beletten zij hiermee. De admiraliteit leende de Directie uit haar magazijnen een zevenentwintigtal stukken geschut, omdat transport van eigen kanonnen vanuit Amsterdam naar Vlissingen vanwege de vorst niet mogelijk was. Teruggave hiervan had overigens in september nog niet plaatsgevonden ${ }^{21}$. Werving van zeelieden voor de kaperschepen leverde geen problemen op, want dit emplooi was vanwege de gerede kans op buitgeld aantrekkelijk. Dit werd spoedig anders, toen in het voorjaar de kapiteins van de oorlogsschepen hun bodems moesten bemannen. Zij konden niets anders bieden dan de vaste, lage gages en bevonden zich in een ongelijke positie. Desertie van individuele of groepjes zeelieden, die zich voor marinedienst hadden opgegeven, naar gereedliggende kapers, kwam meer dan eens voor.

De werving door 'kapiteins-avonturier' werd aan beperkingen onderworpen. Eerst werden zij verplicht een zeker quotum zeelieden voor de vloot aan te nemen, alvorens in zee te mogen gaan, maar dat kwam weldra neer op een dubbele bemanning. In mei 1665 verboden de Staten-Generaal ieder uitzeilen voordat alle oorlogsschepen volledig bemand waren. Het normale patroon van de zeventiende-eeuwse zeeoorlogvoering was een campagne van het late voorjaar tot in het begin van september, waarna het overgrote deel van de oorlogsschepen zijn thuishaven weer opzocht en zijn bemanningen volledig afdankte. Zo kon het gebeuren, dat in september 1665 alle beperkingen ten aanzien vandekaapvaart opgeheven werden, wat tot het voorjaar van 1666 van kracht bleef. Hierna kon de kaapvaart zich evenmin als in 1667 gedurende de zomermaanden volledig ontplooien; dat kon in feite alleen van september tot maart. Het steeds terugkerende tekort aan zeelieden voor de oorlogsvloot was hiervan de oorzaak ${ }^{22}$.

In de derde Engelse oorlog werd de kaapvaart nog sterker aan banden gelegd. Afgezien van een aantal schepen, dat direct bij het uitbreken van de oorlog in zee gelopen was en voornamelijk in Zuideuropese wateren opereerde, kregen kapers niet vóór het einde van juli 1672 hun commissiebrieven uitgereikt. Dat gebeurde toen dan ook op grote schaal, maar de benarde situatie van 1673, met de EngelsFranse vloot gereed voor een invasie in Zeeland of Holland, stond geen kaperactivi-

21. ARA, AA 2484, 2, 4, 7, 14 en 18.2.1665; 2486, 16.9.1665; 2491, 27.1.1667.

22. Ibidem 2484, 14.3; 2485, 13 en $25.4,18$ en 27.5, 27.6; 2486, 27.8 en 14.9; 2487, 11.11.1665; 2490, 20.10.1666; 2491,25.4, 6 en 15.6.1667. Zonder dat een commissiebrief al op zijn naam stond blijkt Daniël Blonkenbijle in maart 1665 een Frans schip opgebracht te hebben (ibidem 2484, 30.3.1665). 
teiten toe en een daarmee gepaard gaand verlies aan zeelieden en schepen voor de verdediging. Diverse kapers meldden zich voor dienst bij de vloot en deden verkenningswerk of verzorgden de berichtgeving. De betrokken admiraliteit betaalde de boekhouders hiervoor een bepaalde huur, waarvan de hoogte afhing van de grootte van de bemanning en van regelingen inzake bewapening en bevoorrading. Telkens werden hiertoe afzonderlijke contracten afgesloten. Buit tijdens dit emplooi behaald, viel geheel aan de kaperrederij toe. In september 1673 werd de commissievaart weer opengesteld en hoewel voor de zomer van 1674 al weereen verbod was afgekondigd werd dit besluit door de vrede van Westminster, vroeg in het voorjaar, achterhaald. Alleen Franse schepen bleven toen als buit over, terwijl de oorlogsvloot minder zeelieden nodig had $^{23}$.

Kaapvaart was derhalve tijdens de derde Engelse oorlog net als in de voorgaande, beperkt tot slechts een gedeelte van het jaar. Of de strenge verbodsbepalingen van de Staten-Generaal strak nageleefd werden, valt moeilijk vast te stellen. In 1665 had de admiraliteit van Amsterdam die van Zeeland ervan beschuldigd dat deze commissievaarders 'vrij en ongehindert' liet uitzeilen. Zeeland had geantwoord dat dit 'tegen waerheit' was en dat juist Amsterdam het land grote afbreuk deed door flinke aantallen goed bemande koopvaarders naar Zuid-Europa te laten vertrekken. Dit soort beschuldigingen ontbreekt waarschijnlijk in de derde oorlog. Ook Zeeland vervolgde toen kapiteins, die de verordeningen overtraden, maar sommige boekhouders waren inventief. Zij pretendeerden dat zij hun schepen naar de West zonden - welke vaart niet verboden was - maar lieten ze dan toch in Europese wateren blijven. Zo zeilden in juni en juli 1673 tenminste negen kapers uit, waaronder vier van Benjamin Raule, met West-Indië als bestemming, maar een aantal van die schepen heeft daarheen beslist niet koers gezet ${ }^{24}$.

\section{OPERATIEGEBIEDEN}

Het is reeds opgemerkt, de kapers beperkten zich bij hun activiteiten niet tot de Noordzee en het Kanaal. In deze zeegebieden behoorden vissersschepen, walvisvaarders en koopvaarders op de Oostzee, Noorwegen en Archangel tot hun prooi. Behalve in de Nederlandse havens werden ook in Glückstadt en Hamburg prijzen opgebracht. Een flink aantal kapers zocht zuidelijker wateren op. In de tweede oorlog was vooral La Rochelle in Frankrijk hun basis en op veel groter schaal dan

23. Cau, ed., Groot Placaet-boeck, III, 231-232, 235-238, 299-303; De Jonge, Geschiedenis, II, 265, 332-337, 355; J. R. Bruijn, ed., De oorlogvoering ter zee in 1673 in journalen en andere stukken. Werken Historisch Genootschap, 3e serie no. LXXXIV (Groningen, 1966) 207, met diverse namen van kaperschepen. Verder ARA, AA 2498,15.5, 5.6, 1.7, 9.8 en 25.9.1673.

24. Ibidem, 2486, 12.9.1665; 2498, 6.4, 20 en $25.5,8$ en 10.7.1673. 


\section{J. R. BRUIJN}

in de tweede oorlog werden hiervoor in de derde oorlog allerlei Spaanse havens gebruikt: La Coruñia, Bilbao en Santander in het noorden, nabij de golf van Biskaje, en Cadiz in het zuiden, bij de toegang tot de Middellandse zee. Een neutrale of welwillende houding van de plaatselijke autoriteiten was altijd nodig. De politieke verhoudingen lagen daarvoor gunstig. De Portugese regering echter stond het opbrengen van Engelse en Franse buit niet toe. Van deze Franse of Spaanse bases uit vielen grote delen van de vijandelijke buiten-Europese scheepvaart - waaronder met name de vaart op West-Indië en Newfoundland - en de Levantvaart binnen hun bereik. Deze koopvaarders waren doorgaans beter bemand en zwaarder bewapend dan de schepen in de eerder genoemde vaarten, zodat het de grotere commissievaarders waren die om de zuid gingen. In januari 1674 bijvoorbeeld verenigden zich voor korte tijd veertien kapers (waaronder zeven uit Vlissingen) nabij Cadiz. $\mathrm{Zij}$ waren met 1.300 a 1.400 koppen bemand, sommige met twintig tot zesendertig stukken bewapend ${ }^{25}$.

In die buitenlandse havens waren het consuls, meestal kooplieden, die als contactpersonen bij het binnenbrengen van prijzen en de verdere afwikkeling ervan optraden. Zij hielden toezicht op de verkoop van schip en lading en brachten met name over de opbrengst aan de betrokken admiraliteit verslag uit. Zij genoten een commissie van één of twee procent. Wat opvalt is, dat de consuls in de voornaamste havens nauwe verwanten van enkele Zeeuwse boekhouders waren: in La Rochelle Jan Raule, van 1672 tot 1674 in Bilbao Jacob Raule, beiden broers van Benjamin Raule en als coördinerend commissaris in Noord-Spanje Nicolaas van Hoorn, familie van Jacob van Hoorn.

De correspondentie van consuls met de admiraliteiten geeft enig inzicht in wat zich overzee bij de kaapvaart afspeelde. Volledig is dit inzicht niet: niet alleen is een deel van de brieven verloren gegaan, maar tevens blijkt menige prijs aan hun waarneming te zijn ontsnapt. Jan Raule merkt bijvoorbeeld op, dat diverse schepen nooit officieel voor goede prijs verklaard werden, maar op het vóór La Rochelle gelegen eilandje S. Martin geplunderd en verkocht werden. De opgaven van prijzen door consuls gedaan, betreffen dus minimumaantallen. Bovendien toont een slepende ruzie tussen Nicolaas van Hoorn en Jacob Raule aan dat Nicolaas geen goede rapporten zond en zelf geregeld schepen op veilingen kocht, wat verboden was. Beide heren werden tenslotte in het begin van 1674 teruggeroepen en tot verantwoording gedwongen $^{26}$.

Een punt dat duidelijk uit deze brieven naar voren komt is dat Nederlandse kapers in beide oorlogen ook in de Middellandse zee opereerden. Dat gebeurde dus

25. C. de Waard, De Zeeuwsche expeditie naar de West onder Cornelis Evertsen den Jonge, 16721674. Werken Linschoten Vereniging, XXX (1928) 58-59; ARA, AA 2499, 11.1.1674.

26. Voorbeelden in ibidem 2486, 5.8.1665; 2488, 27.2.1666; 2498, 30.12.1673; 2499, 17.1, 21.2, 4.5 en 11.7.1674. Zie ook Cau, ed., Groot Placaet-boeck, III, 234-235. 
niet pas in 1692, zoals Bromley veronderstelde. Minstens vijf commissiebrieven, door de admiraliteit van Amsterdam uitgegeven, bevatten een passage dat de houders ervan Malaga, Genua of Livorno als hun basis zouden gebruiken. Ook verschillende malen worden prijzen gemaakt in deze zee vermeld, zoals bijvoorbeeld de 'kostelijck geladen' koopvaarder 'Engeland'. De Zeeuw Jan Sluymers nam dit fregat met een bemanning van achtentwintig koppen op weg van Smyrna naar Napels, in het begin van $1674^{27}$. Toch moet bij al deze overzeese activiteiten niet uit het oog verloren worden, dat het merendeel der prijzen steeds in Nederlandse havens werd opgebracht en het zijn deze aantallen die nog vrij volledig voor de admiraliteiten van Zeeland en Amsterdam achterhaald kunnen worden.

\section{PRIJZEN TIJDENS DE TWEEDE ENGELSE OORLOG GENOMEN}

De beste bron van informatie is de boekhouding van de Amsterdamse vendumeester Elbert Dell. Hij verantwoordde ondermeer vanjaar tot jaar alle prijzen die in zijn ressort verkocht werden. De bruto opbrengst en de verdeling hiervan noteerde hij, evenals de namen van de kapers en van de buitgemaakte schepen tezamen met een omschrijving van de lading. Zulke gegevens ontbreken voor prijzen door Amsterdamse kapers buiten Dell's ressort opgebracht. Voor de Zeeuwse admiraliteit bieden de uitvoerige resolutieboeken inlichtingen; alleen het deel over 1672 is verloren gegaan. Enigszins gelijksoortig materiaal als dat van Dell staat voor de Maze ter beschikking. Alles ontbreekt voor de admiraliteiten van het Noorderkwartier en Friesland. Toevallig vermeldt De Jonge dat een kapitein Arien A uit Hoorn gedurende de jaren 1665 tot 1667 niet minder dan tweeëndertig schepen buitmaakte $^{28}$.

Uit deze bronnen komt naar voren dat ook oorlogsschepen geregeld vijandelijke handelsvaartuigen veroverden en dat hun bijdrage in de oorlogswinst niet verwaarloosd moet worden. Het grootste deel van de opbrengst vloeide in de admiraliteitskassen, maar desondanks vormde buitgeld voor het marinepersoneel een mogelijkheid voor wat extra verdiensten. Van de netto baten van een vijandelijke koopvaarder werd een zesde deel aan de bemanning uitgekeerd, van een bevrijd Nederlands schip slechts één negende. De aantrekkelijkste buit was een oorlogsschip, want daarvan viel de gehele netto opbrengst de veroveraars toe. Ieder lid van de bemanning had recht op een portie, maar de hoeveelheid porties die elk ontving, hing af van de functie die men aan boord bekleedde en van het totaal der opvarenden. Een

27. Bromley, 'Some Zeeland Privateering Instructions', 163. Enkele voorbeelden van prijzen in ARA, AA 2491,27.4.1667 en 2499, 9 en 16.4 en 7.5.1674. De Amsterdamse brieven werden uitgereikt aan Jan Heek, Hendrik Jansz. Coninck en Laurens Gerritsz. Koopman in 1665 en aan Jan Bartelsz. en Jan Cornelisz. Poort in 1672 (ibidem, 1328).

28. De Jonge, Geschiedenis II, 5. 
kapitein kreeg veruit het meeste en een kwartiermeester weer meer dan een ma$\operatorname{troos}^{29}$.

In onderstaande tabel I is de buit door kapers en oorlogsschepen van de admiraliteit van Zeeland en Amsterdam in Nederlandse of buitenlandse havens opgebracht samengevat. Zoals in het voorafgaande reeds is gememoreerd, betreft het dus minimumcijfers voor deze twee admiraliteiten. Van de drie overige admiraliteiten zijn alleen enige toevallige gegevens vermeld. Niet opgenomen zijn de vijandelijke oorlogsschepen, die in een gevecht tot zinken werden gebracht, en evenmin gevallen van rantsoenering. De bronnen zwijgen vrijwel geheel over dit eisen van een losgeld van een op zee aangehouden vijandelijk vaartuig. Had het snel bedervende lading aan boord of was de waarde te gering om een prijsbemanning over te zetten en het naar een haven op te brengen, dan werd een bepaald geldbedrag afgesproken dat naderhand aan de kaper zou worden betaald. De schipper of een andere opvarende werd dan als borg meegenomen ${ }^{30}$.

TABEL I

PRIJZEN IN DE TWEEDE ENGELSE OORLOG GENOMEN

$\begin{array}{lccccc} & \begin{array}{c}\text { oorlogs- } \\ \text { schepen }\end{array} & \begin{array}{c}\text { Zeeuwse } \\ \text { kapers }\end{array} & \begin{array}{c}\text { Amsterd. } \\ \text { kapers }\end{array} & \begin{array}{c}\text { andere } \\ \text { kapers }\end{array} & \text { totaal } \\ \text { Engelse koopvaarders } & 61 & 208 & 52 & 39 & 360 \\ \text { Engelse ladingen } & 3 & 110 & 8 & - & 21 \\ \text { Engelse oorlogsschepen } & 10 & - & - & - & 10 \\ \text { Neutrale koopvaarders } & 10 & 29 & 9 & - & 14 \\ \text { Hernomen koopvaarders } & 1.1 & 3 & - & -\end{array}$

Deze prijzen werden vrijwel gelijkelijk gespreid over de drie oorlogsjaren veroverd. Neutrale schepen werden aangehouden wegens contrabande. Van ongeveer twee derde der Engelse vaartuigen is de aard van de lading min of meer aangegeven. Slechts twaalf prijzen voeren in ballast of waren leeg. De goederen liepen zeer uiteen, zoals zout, olie, krenten, wijnen, vis, huiden, hout, levensmiddelen, maar bijna geen graan. In achtentwintig gevallen betrof het kolenschepen. Suiker en tabak vormden verhoudingsgewijs de meest voorkomende vracht, minstens vijfenzeventig maal. Hierbij ging het waarschijnlijk om export vanuit Engeland, maar zeker even vaak om import uit Barbados, Jamaica of Virginia. Ook werden zeven kapers veroverd.

29. Cau, ed., Groot Placaet-boeck, II, 535, art. 22. Zie ook J. R. Bruijn, De admiraliteit van Amsterdam in rustige jaren 1713-1751 (Amsterdam-Haarlem, 1970) 148.

30. ARA, AA 1806-9 en 2484-92; Baetens, 'Organisatie', 96 noot 12; Bromley, 'Some Zeeland Privateering Instructions' 177 en 184. 
Dankzij Elbert Dell is bekend voor welke bedragen de in Amsterdam aangevoerde prijzen op openbare veilingen verkocht werden ${ }^{31}$. In totaal ging het om zesentachtig verkopingen, waaronder achttien van Zeeuwse kaperbuit. De opbrengst bedroeg f1.530.000.-. Hiervan werd $f 217.000$.- aan Zeeuwse boekhouders uitbetaald en aan Amsterdamse $f$ 567.000.- voor zesenveertig prijzen. Vier koopvaarders geladen met tabaksbladeren uit Virginia en in 1665 door de Amsterdamse kaper Mattijs Jacobsz. Pruyst genomen, haalden met/230.000.- de hoogste opbrengst. Onder deze bedragen vallen niet de prijzen die door Amsterdammers in buitenlandse havens opgebracht werden. Vanuit Cadiz werd opgegeven dat daar voor $f$ 126.000.verkocht was.

Buitgeld moet hoog aangeschreven hebben gestaan bij enkele Amsterdamse oorlogsschepen. De tocht van het eskader onder De Ruyter naar Guinee en de West in 1664-1665, enkele zeeslagen en wat kostbare koopvaarders in de Noordzee veroverd, leverden de bemanningen $f 336.000$.- op. Deze buit vertegenwoordigde op de veilingen een totale waarde van $f$ 675.000.-. Het verschil kwam grotendeels de kas van de admiraliteit ten goede ${ }^{32}$. Na aftrek van onkosten kon bijvoorbeeld kapitein Hendrik Adriaanszoon met zijn equipage $f$ 113.000.- verdelen van de 'Swiftsure', een linieschip van zeventig stukken door hem tijdens de Vierdaagse zeeslag in 1666 prijsgemaakt. De Ruyter's tocht leverde voor Amsterdamse oorlogsschepen bruto f165.000.- op. Een aantal hernomen koopvaarders vertegenwoordigde een waarde van ruim $f 80.000$-.

Voor Zeeland ontbreken dergelijke financiële gegevens. In het oog moet worden gehouden dat Zeeuwse kapers ongeveer viermaal zoveel buit binnen brachten als hun Amsterdamse collega's. De waarde hiervan kan ook bij benadering niet vastgesteld worden.

\section{PRIJZEN TIJDENS DE DERDE ENGELSE OORLOG GENOMEN}

In de jaren 1672-1674 kon zowel op Engelse als Franse schepen jacht gemaakt worden. De oorlog moest door de vloot evenwel defensief gevoerd worden en oorlogskapiteins brachten op veel geringer schaal buit binnen dan in het vorige conflict. Alleen het eskader van Binkes en Evertsen opereerde enige tijd in de West en in Noord-Amerika, terwijl ook wat Amsterdamse konvooischepen onder Schey

31. ARA, AA 1844-1847.

32. Aan de hand van stukken in het Gemeentearchief te Amsterdam wees F. Snapper (Oorlogsinvloeden op de overzeese handel van Holland 1551-1719 (Amsterdam, 1959) 301-302 en aanhangsel 13) als eerste op de zeer hoge inkomsten voor de admiraliteit van Amsterdam uit 'prinsen, mulcten en confiscatiën' gedurende oorlogsjaren. Zijn interpretatie van deze vondst in relatie tot de normale inkomsten van de admiraliteit, is evenwel onjuist. Hij gaat er namelijk aan voorbij dat het overgrote deel weer aan de veroveraars van die 'prinsen' uitgekeerd moest worden. 
bij Cadiz kruisten, beide malen met succes. Tegenover deze kleinere activiteiten van de marine stond de verdubbeling van het aantal kapiteins dat op enigerlei moment ter kaapvaart ging.

De bronnen van informatie over de behaalde buit zijn reeds genoemd, zij zijn dedezelfde als voor de tweede oorlog. Ditmaal is meer bekend over de Maze, maar voor Zeeland ontbreken daarentegen grotendeels gegevens over 1672 . Tot welke nationaliteit de schepen behoorden is soms niet te achterhalen, maar vermoedelijk mag aangenomen worden dat het in drie van de vijf gevallen om Engelse en in de overige twee om Franse schepen ging. Tabel II geeft weer hoeveel buit op zijn minst behaald is en door wie ${ }^{33}$. Er werden geen vijandelijke oorlogsschepen opgebracht en verkocht.

TABEL II

PRIJZEN IN DE DERDE ENGELSE OORLOG GENOMEN

Engelse koopvaarders

Franse koopvaarders

Engelse of Franse koopvaarders

Engelse of Franse ladingen

Neutrale koopvaarders

Hernomen koopvaarders

$\begin{array}{ccccc}\begin{array}{c}\text { oorlogs- } \\ \text { schepen }\end{array} & \begin{array}{c}\text { Zeeuwse } \\ \text { kapers }\end{array} & \begin{array}{c}\text { Amsterd. } \\ \text { kapers }\end{array} & \begin{array}{l}\text { Rotterd. } \\ \text { kapers }\end{array} & \text { totaal } \\ 37 & 151 & 42 & 16 & 246 \\ 10 & 150 & 4 & 3 & 167 \\ 17 & 116 & 40 & 4 & 177 \\ - & 9 & 9 & - & 18 \\ 2 & 11 & - & 12 & 25 \\ 5 & 5 & 6 & - & 16\end{array}$

Van ruim driekwart der prijzen is de globale samenstelling van de lading vermeld. De goederen liepen min of meerop dezelfde wijze uiteen als inde voorgaande oor$\log$, eenmaal betrof het zelfs een lading slaven. Opnieuw werden vijfenzeventig schepen met tabak en suiker veroverd en niet minder dan tweeënvijftig kolenschepen. Bij een verklaring voor de problemen die Londen tijdens de Engelse oorlogen ondervond bij de kolenvoorziening, moeten meer dan in Nef's mededelingen daarover, de acties van kapers in aanmerking genomen worden ${ }^{34}$. Het opvallendst echter is het grote aantal vaartuigen, vierennegentig, dat haring, zalm en vooral vis van Newfoundland aan boord had. Het verlies van een zestigtal Terreneufsvaarders moet in 1673 de aanvoer in Frankrijk soms verstoord hebben, terwijl Spanjaarden daarentegen konden profiteren van dit in hun havens goedkoop verkochte levensmiddel. Ook werden acht Franse en een Engelse kaper opgebracht. In vierenveertig gevallen bestond de oogst slechts uit een leeg of geballast schip.

33. ARA, AA 636-637, 743, 1813-1815, 2498-2499 en XXXVII, 115.

34. J. U. Nef, The Rise of the British Coal Industry, II (Londen, 1932) 93-94,205-6 en 234. In T. S. Willan, The English Coasting Trade 1600-1750 (2e dr., Manchester, 1967) 24 en 28-32 wordt hierop duidelijker gewezen. 
Over de opbrengst van de verkoop van in Amsterdam aangevoerde schepen en ladingen worden we opnieuw ingelicht door Elbert Dell ${ }^{35}$. Het ging om $f$ 1.487.000.-, een nagenoeg gelijk bedrag als in de jaren 1665-1667 en het resultaat van honderdelf veilingen. Zeeuwse boekhouders zagen het grootste rendement van hun uitredingen, want de bruto baten uit negenentwintig prijzen beliepen $f$ 812.000.-. Abraham van Pere dankte aan zijn kaper Isaac Rochussen $f$ 350.000.- voor het in 1672 veroverde Engelse retourschip de 'Gouden Valk', terwijl een verduisterde hoeveelheid diamant en juwelen niet achterhaald kon worden. Een jaar later kreeg hij nog weer $f$ 105.000.-, toen Cornelis Marinusse twee Engelse met suiker en 'boomwol' geladen schepen opbracht. De onzuivere opbrengst van drieënzestig Amsterdamse prijzen was $f$ 581.000.-. Deze en andere boekhouders te Amsterdam zagen hun kapers in Cadiz voor $f$ 283.000.- buit veilen. Om hoeveel schepen het ging en wat elders door hen werd opgebracht, is niet bekend.

Vendumeester Dell kon aanvankelijk slechts $f$ 13.000.- aan buitgeld over prijzen ter waarde van $f$ 81.000.- aan kapiteins en bemanningen van Amsterdamse oorlogsschepen uitkeren. Naderhand kwamen daar de provenuen bij voor het eskader in de West bij (minstens $f$ 86.000.- buitgeld). De konvooireis van Schey bracht $f 194.000$.- op, waarvan $f$ 26.000.- voor buitgeld bestemd werd. Voor Willem III betekenden al deze in de Amsterdamse boekhouding verantwoorde prijzen een bedrag aan tiende penningen van bijna $f$ 175.000. ${ }^{36}$.

In Rotterdam werden tweeënveertig veilingen gehouden, die $f 316.000$.- opbrachten. Amsterdamse boekhouders lieten hier twaalf prijzen voor $f$ 54.000.- verkopen, hun Zeeuwse collega's slechts voor $f$ 14.000.-. De rest was voor Rotterdammers zoals Engelbert Hennekijn. Sommige ladingen wijn leverden hun veel $\mathrm{op}^{37}$.

\section{SLOTBESCHOUWING}

Het bezit van een commissiebrief was voor kapitein en boekhouder nimmer een vrijbrief om zonder enige beperking verder hun gang te kunnen gaan. Kaapvaart was een oud en gereglementeerd bedrijf en hierop werd door de admiraliteiten toegezien, zeker tijdens deze twee oorlogen. Uit verschillende gevallen blijkt dat bijvoorbeeld de Zeeuwse admiraliteit optrad tegen overtreders. Soms gebeurde dat ook bij een geschil tussen boekhouder en kapitein. Tijs Quaerts die in 1666 reeds enkele prijzen in La Rochelle had opgebracht, liet daar in de zomer van dat jaar een Engelse fluit tegen zekere instructies in toch verkopen. Zijn boekhouder verzocht om een onderzoek. Ook de admiraliteit schoot er geld bij in. Consul Jan Raule

35. ARA, AA 1851, 1851», 1852. Voor de 'Gouden Valk' zie ook 2498, 2.1.1673.

36. Ibidem 1874, 1876-1877 en 1883.

37. Ibidem 743 . 


\section{J. R. BRUIJN}

moest de kaperbrief innemen en Quaerts werd tenslotte in Zeeland in hechtenis genomen. Na meer dan een halfjaar kwam hij pas vrij, toen hij met zijn boekhouder en de admiraliteit tot een accoord was gekomen ${ }^{38}$.

Ook werden maatregelen genomen tegen wangedrag ten opzicht van opvarenden van een prijs of tegen plundering. Quirijn Mangelaer maakte zich in 1665 aan beide feiten schuldig. Hijzelf en enkele leden van zijn bemanning werden gearresteerd. Door interventie van de Staten-Generaal op verzoek van de Zweedse gezant maakte de Zeeuwse admiraliteit de verovering in 1672 van twee koopvaarders door Jan Sluymers ongedaan ${ }^{39}$.

Herhaaldelijk kwam het voor dat kapiteins hun scheepsvolk niet in de hand konden houden. Wanneer zij of hun boekhouders zich hierover beklaagden, werden zo mogelijk de schuldigen aan de 'onordentelijckheden' gearresteerd of beboet. Over het algemeen krijgt men de indruk dat het Zeeuwse admiraliteitsbestuur niet lankmoedig was en dat het ook via de consuls toezicht op de handelingen van de kapers probeerde te houden ${ }^{40}$.

Er zijn geen aanwijzingen dat de admiraliteit van Zeeland in belangrijke geschillen over prijsverklaringen met de vroegere eigenaars van de prijs, de boekhouder van de kaper of met een andere admiraliteit verwikkeld was. Een probleem met Amsterdam over betaling van de rantsoenpenningen en de centesimo, geheven van Zeeuwse buit in Amsterdam opgebracht en geveild, kon in 1665 vlot opgelost worden. Op basis van wederkerigheid werd afgesproken in dergelijke gevallen de helft over te maken naar de admiraliteit, onder welker jurisdictie de kaper voer ${ }^{41}$. Het blijkt steeds weer dat het kapersbedrijf niet iets nieuws was, maar naar bestaande en beproefde regels bedreven werd.

Het uitreden-van schepen voor de commissievaart was nooit een-garantie voor-een voordelige exploitatie. Door de zee of de vijand kon een schip verloren gaan. Dit gebeurde waarschijnlijk niet vaak. In de tweede oorlog bijvoorbeeld overkwam dit aan vijf Zeeuwse kapers. Voor de betrokken kapiteins betekende het doorgaans niet meer dan een incident. Cornelis Evertsen, Pieter van Goethem of Andries Mijster verspeelden er hun reputatie niet mee. De Amsterdammer Adriaan Quast werd in 1672 met zijn 'Gele Teerkwast' door een Engels oorlogsschip opgebracht en zijn 'Tarbrush' werd verbeurd verklaard, maar het volgende jaar wreekte hij zich door twee vijandelijke scheepjes te veroveren ${ }^{42}$. Het verlies van het kapervaartuig droeg

38. Ibidem 2489, 5.7 en 25.8.1666; 2491, 20.6.1667.

39. Ibidem 2486, 12 en 14.9 en 6.10.1665; 2488, 29.1.1666 (Mangelaer). Ibidem 2498, 23.1, 25.2 and 4.9.1673 (Sluymers).

40. Voorbeelden van (optreden tegen) wangedrag in ibidem 2485, 8.4.1665; 2488, 14.1.1666; 2498, 13.1, 7.8 en 14.10.1673. Toezicht door consuls in ibidem 2491, 2.3 en 20.4.1667.

41. ARA, AA 2487, 24.10, 2.11 en 21.12.1665; 2498, 21.6.1673.

42. Ibidem 2485, 30.5.1665 (Evertsen); 2486, 8.8.1665 (Bosse); 2489, 7.8.1666 (Van Goethem); 2491,11.6.1667 (Mangelaer); De Waard, XX (Mijster). Voor Quast zie ibidem 1814,20.12.1673 en 1815, 11.1.1674 en R. G. Marsden, ed., 'Documents Relating to Law and Custom of the Sea, II', Navy Records Society, L (1916) 82-84. 
de boekhouder met de andere partenhouders, onder wie soms de kapitein zelf. Groter echter was de kans dat er geen buit behaald kon worden. Van ongeveer de helft van de Amsterdamse commissievaarders is althans niet bekend, dat zij ook maar eenmaal succes hadden. Bij de Zeeuwen lag de verhouding veel gunstiger, want in de twee oorlogen wisten respectievelijk vierenzeventig van de drieënnegentig en honderdvierentwintig van de honderdvierentachtig een schip of alleen een lading in beslag te nemen. Het ontbreken van opgaven van prijzen door Amsterdammers in het buitenland aan de wal gebracht, kan deze ongelijkheid gedeeltelijk verklaren.

Het is niet verantwoord een gemiddelde opbrengst van de buit per kaper aan de hand van de cijfers van de Amsterdamse vendumeester vast te stellen. Daarvoor lopen de bedragen te zeer uiteen. Zes- of zevenhonderd gulden is evenmin een uitzondering als veertigduizend. De in het voorafgaande genoemde hoge getallen zijn uitschieters en zouden een berekening vertekenen. Toch zal het succes van een Abraham van Pere tot navolging geprikkeld hebben. Voor menig boekhouder met slechts één of twee kaperschepen moet de commissievaart bijzaak geweest zijn. Jacob Bisschop had geen geluk met Paulus Andriessen in de derde oorlog, maar Johan Ghijsseling daarentegen wel met Andries Mijster, die in diezelfde jaren minstens zestien prijzen in Spaanse en Zeeuwse havens binnenbracht. Dat Raule's moeilijkheden, die hem in 1675 de Republiek deden verlaten, voortvloeiden uit de financiële resultaten van de kaapvaart, valt niet aan te nemen. Zijn kapiteins veroverden diverse tientallen Engelse en Franse schepen. Overigens is van de exploitatiekosten van kaperschepen niets bekend.

Vast staat dat op de veilingen in Amsterdam en Rotterdam in totaal voor een bedrag van bijna $f 3.500 .000$.- aan oorlogsbuit werd omgezet, wat Rotterdam betreft in de derde en wat Amsterdam betreft in de tweede en derde oorlog ${ }^{43}$. Het ging daarbij om tweehonderdnegenendertig prijzen, zowel Engelse, Franse als neutrale schepen en ladingen en ook om bevrijde Nederlandse vaartuigen. Maar niet minder dan 1.102 van dergelijke gevallen konden gevonden worden. Vooral het ontbreken van vollediger gegevens, ook van financiële aard, over hetgeen zich in buitenlandse havens afspeelde, ontneemt ons de mogelijkheid voor een meer complete waardering van de kaperactiviteiten. De toevallige cijfers over de opbrengst van Amsterdamse prijzen in Cadiz en die over aantallen schepen door Zeeuwen in Spanje en Frankrijk binnengebracht, doen vermoeden dat eerder onderschatting dreigt dan overschatting. Wat in West-Indië gebeurde, kwam slechts zelden in de bescheiden van de admiraliteit terecht. Van welke betekenis de commissievaart in het Noorderkwartier en Friesland was, kan zelfs niet bij benadering gezegd worden. Ook hier moet men zich hoeden voor onderschatting.

43. Het bedrag van $f$ 1.172.000.- dat de Zeeuwse admiraliteit over 1672-1674 aan buitgeld ontving, vermeld door De Jonge Geschiedenis, II, 477 noot 1, is moeilijk te interpreteren. 
In ieder geval nam kaapvaart een veel belangrijker plaats in bij de oorlogvoering dan tot nog toe werd aangenomen. Zeker tijdens de derde Engelse oorlog deden de Zeeuwen niet onder voor de Duinkerkers in de dagen van Tromp en alleen reeds de Amsterdamse veilingopbrengsten kunnen een vergelijking met de Vlaamse rondom 1630-1640 doorstaan ${ }^{44}$. De 'Verstoorde Leeuw' sloeg bepaald zijn klauwen uit! De uitrusting van de kaperschepen en de verkoop van allerhande goederen zullen de bedrijvigheid in de zeehavens gestimuleerd hebben, in Amsterdam natuurlijk op een geringer schaal dan bijvoorbeeld in Vlissingen of Zierikzee. De veroverde vaartuigen vulden geleden verliezen weer enigszins aan. De commissievaart bood emplooi voor zeelieden en schepen, die anders door de embargo's op de koopvaardij geheel of gedeeltelijk werkeloos en ongebruikt waren gebleven. De kapiteins van Raule konden met vaak dezelfde schepen met weliswaar minder vreedzaam oogmerk dezelfde zeegebieden opzoeken als voorheen in vredestijd ${ }^{45}$. Of verder vooral boekhouders en schippers betrokken bij de handel op West-Afrika en West-Indië zich op de commissievaart wierpen, zal nader onderzoek moeten uitwijzen ${ }^{46}$.

De admiraliteiten trokken wel profijt van oorlogsbuit door hun eigen schepen behaald, bijna niet van commissievaarders. Het kon in het eerste geval soms om aanmerkelijke bedragen gaan, zoals bijvoorbeeld in de jaren 1665-1667 bij het college van Amsterdam (ruim $f$ 300.000.-). In de derde Engelse oorlog was hier veel minder sprake van. De verliezen die zij door de oorlogvoering leden in hun inkomsten uit de in- en uitvoerrechten werden geenszins gecompenseerd.

Hoe kwamen Samuel Pepys en andere tijdgenoten evenwel aan hun geringe dunk van de activiteiten van Nederlandse commissievaarders? De grote verliezen door de in vergelijking met de Nederlandse nog kleine Engelse koopvaardij geleden, moeten niet onopgemerkt zijn gebleven: op zijn minst driehonderzestig in de tweede en waarschijnlijk ongeveer evenveel in de derde oorlog. Of bleven deze verborgen achter de Engelse scheepswinsten van respectievelijk vijfhonderdtweeëntwintig en vijfhonderd, die ze weer aanvulden? Als men rekening houdt met de onvolledigheid van deze Nederlandse cijfers, zullen de Engelse verliezen in aantallen schepen niet veel kleiner geweest zijn dan de winsten. Over de gemiddelde grootte van de Nederlandse en Engelse prijzen is niets bekend, maar wel kan gesteld worden dat de door Davis voor 1675 geconstateerde sterke toeneming van vreemde tonnage onder

44. Vergelijk Baetens, 'Organisatie', 98-99, 106-109.

45. Rijksarchief in Zeeland, Handschriften 198 en 202.

46. Zie bijvoorbeeld Abraham van Pere en Pieter van Rhee (C. C. Goslinga, The Dutch in the Caribbean and on the Wild Coast 1580-1680 (Assen, 1971) 102, 343, 429; dit werk biedt overigens verder weinig informatie dienaangaande). Verder L. C. Vrijman, Dr. David van der Sterre. Zeer aenmerkelijke reysen gedaan door Jan Erasmus Reyning (Amsterdam, 1937) 143-168. Reizen in vredestijd door de Amsterdamse kapers Pieter Fonteyn en Joris Simonsz. Strijd (zie aktes in Gemeentearchief Amsterdam, Notariële-Archieven 3598,25.11.1676en 2297 II, 49.51, 8.11.1668) wijzen hier wellicht ook op. Zie ook Bromley, 'Some Zeeland Privateering Instructions', 187-188. 
de Engelse koopvaardijvloot niet alleen verklaard moet worden uit de verovering van Nederlandse schepen. Verlies van vele in eigen land gebouwde bodems droeg hiertoe ook bij.

Tot de Nederlandse buit behoorden allerhande types van schepen. Van ongeveer de helft werd het type in de rekeningen en de resolutieboeken opgetekend. Gebruikt men deze opgaven als maatstaf voor het totale aantal dan verloren de Engelsen ongeveer honderddertig kitsen, honderdtwintig grote en kleine pinassen, maar ook honderd fluiten. Het verlies van deze laatste schepen moet het door Davis gesignaleerde gebruik van dit bij uitstek Nederlandse vrachtschip in de Engelse koopvaardij geremd hebben ${ }^{47}$.

47. Davis, The Rise, 52-54. 


\section{Nederland en de rang van Denemarken*}

\section{H. BAUDET}

In het najaar van 1970 hield het Nederlands Historisch Genootschap een congres over (zoals het programma dat met in dit gezelschap verrassend anachronistische terminologie noemde) de Nederlandse expansie in Indonesië. Daarbij had men dan in het bijzonder 'de tijd van het moderne imperialisme, 1870-1914' op het oog. Ik behoorde daar wel tot de sprekers maar vond, dat ik enige redenen had om toch geen tekst af te staan voor publicatie in de congresbundel. Een echte voordracht had ik, naar mijn mening, trouwens niet gehouden. Ik had mij bepaald tot alleen wat toelichting op een paar vooraf geformuleerde gezichtspunten en met de keuze van die gezichtspunten had ik mij nauwelijks laten leiden door de aangegeven periode van het congresthema. Maar van mijn voornemen om korte tijd later daarop uitvoeriger terug te komen werd ik vervolgens door ander werk en andere interessen, waar nooit veel tegen te doen valt, toch weer afgehouden. Zo is het voorlopig ongeveer gebleven bij waar ik was in 1970, dat is bij de verder niet gepubliceerde stellingen, die ik toen aan dat congres heb voorgelegd. Zij blijven bedoeld voor een boek, dat ik ooit nog hoop te schrijven en dat dan 'Het economisch argument van Nederland in Indië' zou kunnen heten.

Dat is allemaal wel begonnen in mijn tijd bij het Algemeen Nederlands Persbureau. Toch kwam de eerste werkelijke aanzet tot een dergelijk boek van de betrekkelijk toevallige omstandigheid, dat ik, een jaar of zes geleden, een artikel had op te leveren over de economische consequenties, die het verlies van de koloniën voor $\mathrm{Ne}$ derland had gehad. Dan moesten enige opmerkingen gemaakt worden over het merkwaardig contrast tussen enerzijds de zwarte onheilsverwachtingen, die hier in de jaren 1945-1946 en ook nog wel later leefden omtrent de nationale economie, als die het straks misschien zonder Indië of Indonesië zou moeten stellen - en de uitkomsten anderzijds, die zich onder de meest tegenstrijdige lotswisselingen niettemin in de volgende twintig jaar realiseerden. Men komt terecht bij vergelijkingen tussen opvattingen 'ex ante' en ervaringen 'ex post', maar ook bij alle complicaties van het feit, dat die beide niet als onafhankelijke variabelen kunnen worden be-

* Dit artikel is ook opgenomen in de bundel: H. Lamberts, R. O. Huisingh en F. A. van Brouwershaven, ed., Ondernemer en omgeving. Opstellen geschreven voor H. Stout bij zijn afscheid als voorzitter van de raad van bestuur van Internatio-Müller NV (Rotterdam, 1975, niet in handelsuitgave verkrijgbaar). 